\title{
Electron Microscopic Study of the Cell Surface of Dibekacin-Treated Pseudomonas aeruginosa
}

\author{
Seitchi Aonuma, Fumio AriJi, Kotaro Oizumi and \\ Kiyoshi Konno \\ Department of Internal Medicine, the Research Institute for \\ Tuberculosis and Cancer, Tohoku University, Sendai 980
}

Aonuma, S., Arisi, F., Oizumi, K. and Konno, K. Electron Microscopic Study of the Cell Surface of Dibekacin-Treated Pseudomonas aeruginosa. Tohoku J. exp. Med., 1986, 150 (1), 69-75_Electron microscopy of thin sections of Pseudomonas aeruginosa IAM 1007 treated with dibekacin revealed blebs, disintegration of the outer membrane of the cell wall and degenerative features of the cytoplasm. In the next experiment, the cell wall fraction was isolated from the mechanically disrupted cells, incubated with dibekacin and was subjected to electron microscopy, in order to find a clue to the action mechanism of dibekacin on the cell wall of Pseudomonas aeruginosa IAM 1007. As a result, it was found that unidentified substances were released from the surface of the cell wall and that the outer membrane of the cell wall disappeared. The degree of changes of the cell wall ultrastructure was almost proportional to the length of incubation with dibekacin. These findings strongly suggest that dibekacin directly disintegrates the outer membrane of the cell wall of Pseudomonas aeruginosa IAM 1007. - electron microscopy; pseudomonas; dibekacin

The aminoglycoside is an antibiotic which inhibits protein synthesis of bacteria. Up to the present, several investigators (Fukushi and Hirano 1973 ; Iida and Koike 1974; Nishino and Nakazawa 1975) have described ultrastructural changes of the cell surface of Pseudomonas aeruginosa incubated with aminoglycosides. But it has not yet been confirmed whether these morphological changes were caused by direct actions of aminoglycosides on the cell surface.

In this study, the ultrastructural changes of the surface of the isolated cell wall fraction and the resting cell of dibekacin-treated Pseudomonas aeruginosa IAM 1007 were investigated by electron microscopy, in order to find out whether dibekacin directly causes the changes of the cell wall.

\section{Materials and Methods}

An overnight culture in heart infusion broth at $37^{\circ} \mathrm{C}$ of Pseudomonas aeruginosa IAM 1007, against which the minimum inhibitory concentration (MIC) of dibekacin was $0.78 \mu \mathrm{g} /$ ml, was used throughout this study.

Received March 26, 1986; accepted for publication July 14, 1986. 


\section{Electron microscopy}

Electron micrographs with magnification higher than $\times 30,000$ were taken, because low-magnification electron micrographs failed to reveal any change in ultrastructure with certainty.

\section{Dibekacin-treated Pseudomonas aeruginosa}

The suspension of $6 \times 10^{7}$ bacterial cells $/ \mathrm{ml}$ at a logarithmic phase in heart infusion broth was incubated at $37^{\circ} \mathrm{C}$ for $2 \mathrm{hr}$ with $12.5 \mu \mathrm{g} / \mathrm{ml}^{*}$, and $0.78 \mu \mathrm{g} / \mathrm{ml}$ dibekacin respectively. ( ${ }^{*}$ This concentration, which was more than ten times that of MIC, was chosen, so that morphological changes became evident within a short period of incubation time). The dibekacin-treated and untreated bacterial cells were fixed with $1 \% \mathrm{OsO}_{4}$ in acetate-veronal buffer of Michaelis ( $\mathrm{pH}$ 6.1). The fixed bacterial cells were treated with $0.5 \%$ uranyl acetate for $1 \mathrm{hr}$, dehydrated in a ethanol series and embedded in Epon 812. The ultrathin sections were stained with uranyl acetate and lead citrate, and were observed with a Hitachi HS-8 electron microscope.

In an experiment which was undertaken to confirm the presence, or absence of direct effects of dibekacin on cell surface structure, the whole bacterial cells of the resting Pseudomonas aeruginosa IAM 1007 were kept overnight in saline at $4^{\circ} \mathrm{C}$, incubated with dibekacin in saline as above and were negatively stained with $0.5 \%$ uranyl acetate.

\section{Isolated cell wall of dibekacin-treated pseudomonas aeruginosa}

The bacterial cells were harvested, washed with saline and were suspended in saline at a concentration of $50 \mathrm{mg}$ of wet bacterial cells $/ \mathrm{ml}$. Thereafter they were disrupted with a Sorval-Ribi refrigerated cell fractionator at 15,000 psi.

This suspension containing disrupted bacterial cells was centrifuged for $20 \mathrm{~min}$ at $8,000 \times \mathrm{g}$. The resulting supernate was then centrifuged for $30 \mathrm{~min}$ at $105,000 \times \mathrm{g}$. The precipitate containing the cell wall fraction was kept overnight in saline at $4^{\circ} \mathrm{C}$, to which 10 $\mu \mathrm{g} / \mathrm{ml}$ and $0.78 \mu \mathrm{g} / \mathrm{ml}$ of dibekacin was added subsequently. Samples were taken therefrom and incubated for $30 \mathrm{~min}, 60 \mathrm{~min}$ and $120 \mathrm{~min}$, either at $37^{\circ} \mathrm{C}$ or $4^{\circ} \mathrm{C}$. The drug-treated cell wall fraction was negatively stained with $0.5 \%$ uranyl acetate and was observed with an electron microscope. The cell wall fraction incubated in drug-free saline was used as a control.

\section{RESUlts}

An electron micrograph of the thin section of untreated Pseudomonas aeruginosa IAM 1007 shows the cell wall with a triple layered structure consisting of a double layered outer membrane and a thinner, unilayered inner membrane. The cytoplasmic membrane within the inner layer of the cell wall shows a double membrane structure. The cytoplasm is filled with ribosomal particles. The nucleus which is usually found in the central portion of the cell is filled with fine fibrils (Fig. 1). An electron micrograph of the thin section of the bacterial cell treated with $12.5 \mu \mathrm{g} / \mathrm{ml}$ of dibekacin in heart infusion broth revealed blebs on the outer membrane of the cell wall, rupture of the cell membrane and degenerative features of ribosomes in the cytoplasm (Fig. 2).

The cell surface of the untreated Pseudomonas aeruginosa IAM 1007 is smooth as shown in Fig. 3 (negatively stained specimens)

In the bacterial cells at resting state, incubated with $12.5 \mu \mathrm{g} / \mathrm{ml}$ of dibekacin 
in saline at $37^{\circ} \mathrm{C}$ for $2 \mathrm{hr}$, there were bleb-like processes, partial defect of the cell surface and rupture at several sites of the cell membrane (Fig. 4). However, such destructive changes were much less remarkable in the cells treated with $0.78 \mu \mathrm{g} /$ $\mathrm{ml}$ of dibekacin.

The untreated cell wall fraction had a smooth-surfaced uniform structure as shown in Fig. 5. When the cell wall fraction was incubated with $10 \mu \mathrm{g} / \mathrm{ml}$ of dibekacin in saline at $37^{\circ} \mathrm{C}$ for $30 \mathrm{~min}$, unidentified substances were found to be released from the surface of the cell wall (Fig. 6). When the specimens were treated with $10 \mu \mathrm{g} / \mathrm{ml}$ of dibekacin at $37^{\circ} \mathrm{C}$ for $60 \mathrm{~min}$, most of the outer membrane was destroyed with concomitant appearance of the naked inner membrane. The residual outer membrane was rather coarse. Also it was found that the cell wall in most bacteria was disintegrated to the same extent (Fig. 7). After treatment for $120 \mathrm{~min}$, the cell wall, which had lost the outer membrane, became an extremely thin leaflet (Fig. 8). But these morphological changes of cell wall fractions incubated with $0.78 \mu \mathrm{g} / \mathrm{ml}$ of dibekacin were much less remarkable. No remarkable changes were observed in any cell wall fractions when incubated in drug-free saline at $37^{\circ} \mathrm{C}$ for $120 \mathrm{~min}$ or incubated with $10 \mu \mathrm{g} / \mathrm{ml}$ of dibekacin at $4{ }^{\circ} \mathrm{C}$.

Figs. 6,7 and 8 show that the degree of destruction of the cell wall was almost proportional to the length of incubation period.

\section{Discussion}

Inhibition of protein synthesis has been proposed as one of the mechanisms which are responsible for the antimicrobial action of aminoglycosides, and evidence which supports this theory has been accumulated (Wolfgang and Lawrence 1968; Siddiqui 1972; Ohtsuki et al. 1978). The electron micrographs of the cells of dibekacin-treated Pseudomonas aeruginosa IAM 1007 in the present experiment revealed severe destruction of the cell wall, which was often in association with leakage of the intra-cellular substances. Degeneration of ribosomes, which might support the theory that dibekacin inhibits protein synthesis was observed also. Such characteristic destructive changes of the cell wall caused by aminoglycosides have already been reported by several investigators (Fukushi and Hirano 1973; Iida and Koike 1974; Nishino and Nakazawa 1975). But the action mechanism of aminoglycosides which is responsible for these changes has not yet been elucidated.

In order to find out whether destruction of the cell wall is due to the direct action of aminoglycosides on cell surface structure, or due to inhibition of protein synthesis, the effect of dibekacin on the cell wall isolated from the mechanically disrupted cells was examined. It was found that unidentified substances, presumably constituents of the outer membrane of the cell wall were released gradually from the surface of the isolated cell wall fraction. Finally the outer membrane disappeared from the cell wall structure, which then became a thinner unilayered 
leaflet. Similar changes in cell surface ultrastructure were observed also in resting whole cells, after overnight incubation in saline at $4^{\circ} \mathrm{C}$ and treated with dibekacin in saline. It was found also that the degree of changes in cell surface ultrastructure was almost proportional to the length of incubation period. These findings strongly suggested that dibekacin directly disintegrated the outer membrane of the cell wall of Pseudomonas aeruginosa.

\section{References}

1) Fukushi, K. \& Hirano, T. (1973) Electron microscopic study of Pseudomonas aeruginosa treated with 3',4'-dideoxykanamycin B. Kosankinbyo Kenkyu-Zassi, 25, 134-137. (Japanese)

2) Iida, K. \& Koike, M. (1974) Cell wall alternations of gram-negative bacteria by aminoglycoside antibiotic. Antimicrob. Agents Chemother., 5, 95-97.

3) Nishino, T. \& Nakazawa, S. (1975) Morphological alterations of Pseudomonas aeruginosa by aminoglycoside antibiotics. J. Electronmicrosc., 24, 73-86.

4) Ohtsuki, M., Yamagishi, J., Nishino, T. \& Nakazawa, S. (1978) Bacteriological evaluation of sisomicin, a new aminoglycoside antibiotic. Chemotherapy., Suppl. 3, $52-69$.

5) Siddiqui, M.A., Nicholson, D. \& Snider, P.J. (1972) Certain aspects of streptomycin inhibition of protein synthesis in Serratia marcescens. J. Antibiot., 25, 54-59.

6) Wolfgang, R.W. \& Lawrence, N.L. (1968) Intracellular distribution of ${ }^{3} \mathrm{H}-$ dihydrostreptomycin in a streptomycin-dependent strain of Bacillus megaterium. $J$. Bact., 95, 1295-1299.

Fig. 1. A thin section of untreated Pseudomonas aeruginosa IAM 1007. The cell wall shows a triple-layer structure consisting of a double layered outer membrane and a thinner, unilayered inner membrane (the peptidoglycan layer). $\quad \times 65,000$

Fig. 2. A thin section of Pseudomonas aeruginosa IAM 1007 treated with $12.5 \mu \mathrm{g} / \mathrm{ml}$ of $\mathrm{DKB}$ at $37^{\circ} \mathrm{C}$ for $2 \mathrm{hr}$.

Blebs on the outer membrane of the cell wall, rupture of the cell membrane and degenerative features of the cytoplasm are observed. $\times 38,000$

Fig. 3. An electron micrograph of untreated Pseudomonas aeruginosa IAM 1007 (control) negative-stained with $0.5 \%$ uranyl acetate. Its surface is smooth. $\times 18,000$

Fig. 4. An electron micrograph of negative-stained whole cell of Pseudomonas aeruginosa IAM 1007 incubated with $12.5 \mu \mathrm{g} / \mathrm{ml}$ of dibekacin (DKB) in saline at $37^{\circ} \mathrm{C}$ for $2 \mathrm{hr}$. The cell surface is uneven. Note some processes, defects on the cell surface, and rupture of the cell membrane. $\times 30,000$ 


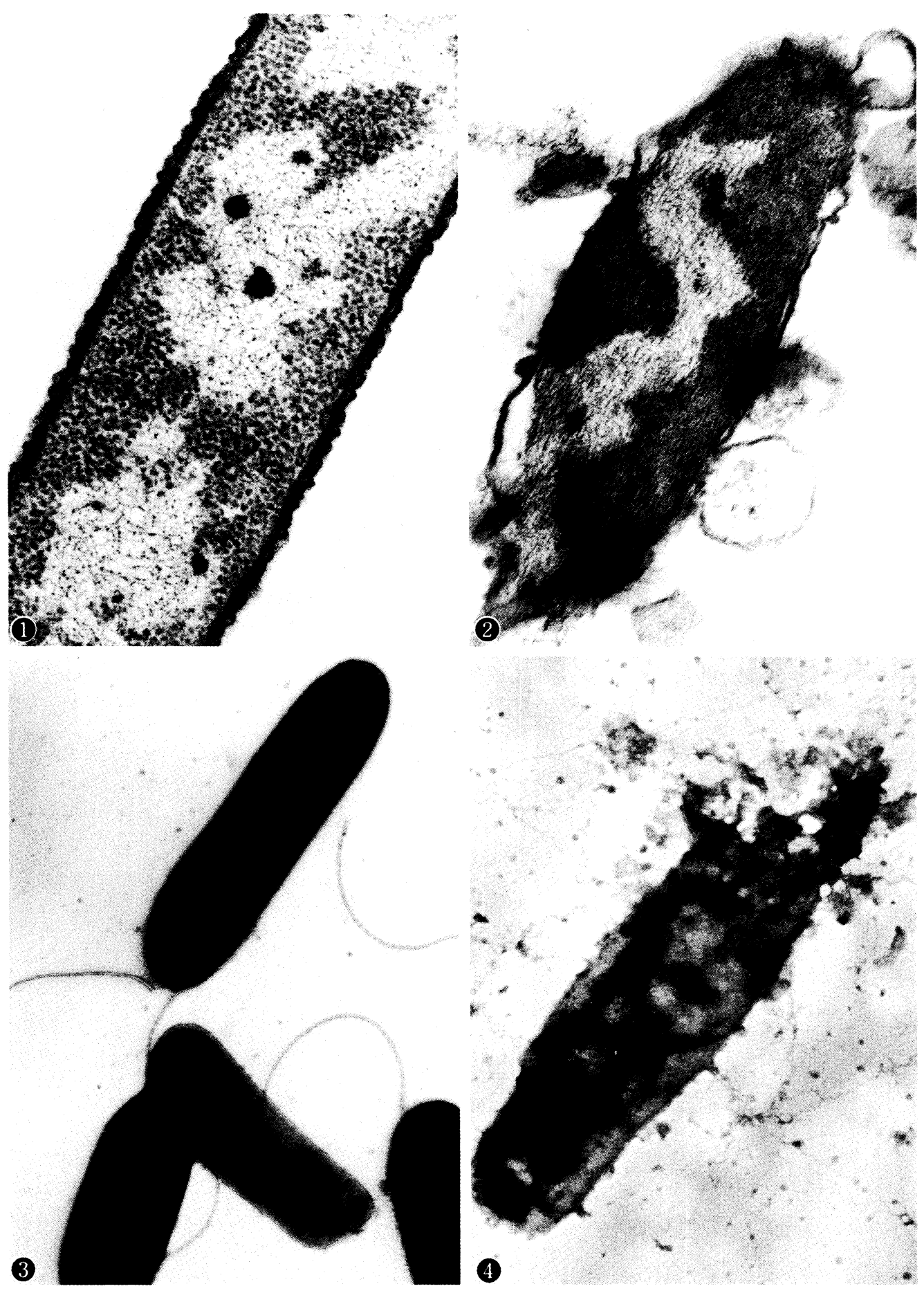


Fig. 5. An electron micrograph of the cell wall fraction, prepared from negative-stained untreated Pseudomonas aeruginosa IAM 1007. The surface of the cell wall is smooth. $\times 64,000$

Fig. 6. An electron micrograph of the negative-stained cell wall fraction treated with 10 $\mu \mathrm{g} / \mathrm{ml}$ of $\mathrm{DKB}$ at $37^{\circ} \mathrm{C}$ for $30 \mathrm{~min}$ in saline. Unidentified substances are released from the cell wall, and the cell surface appears coarse. $\quad \times 50,000$

Fig. 7. An electron micrograph of the negative-stained cell wall fraction after treatment with $10 \mu \mathrm{g} / \mathrm{ml}$ of $\mathrm{DKB}$ at $37^{\circ} \mathrm{C}$ for $60 \mathrm{~min}$. Two pieces of cell wall fractions are seen. Most of the outer membrane is lost and the inner membrane is exposed. $\quad \times 35,000$

Fig. 8. An electron micrograph of the negative-stained cell wall fraction after treatment with $10 \mu \mathrm{g} / \mathrm{ml}$ of $\mathrm{DKB}$ at $37^{\circ} \mathrm{C}$ for $120 \mathrm{~min}$ in saline. Cell walls are broken into fragments, which show a thinner unilayered structure without outer membrane. $\times 45,000$ 


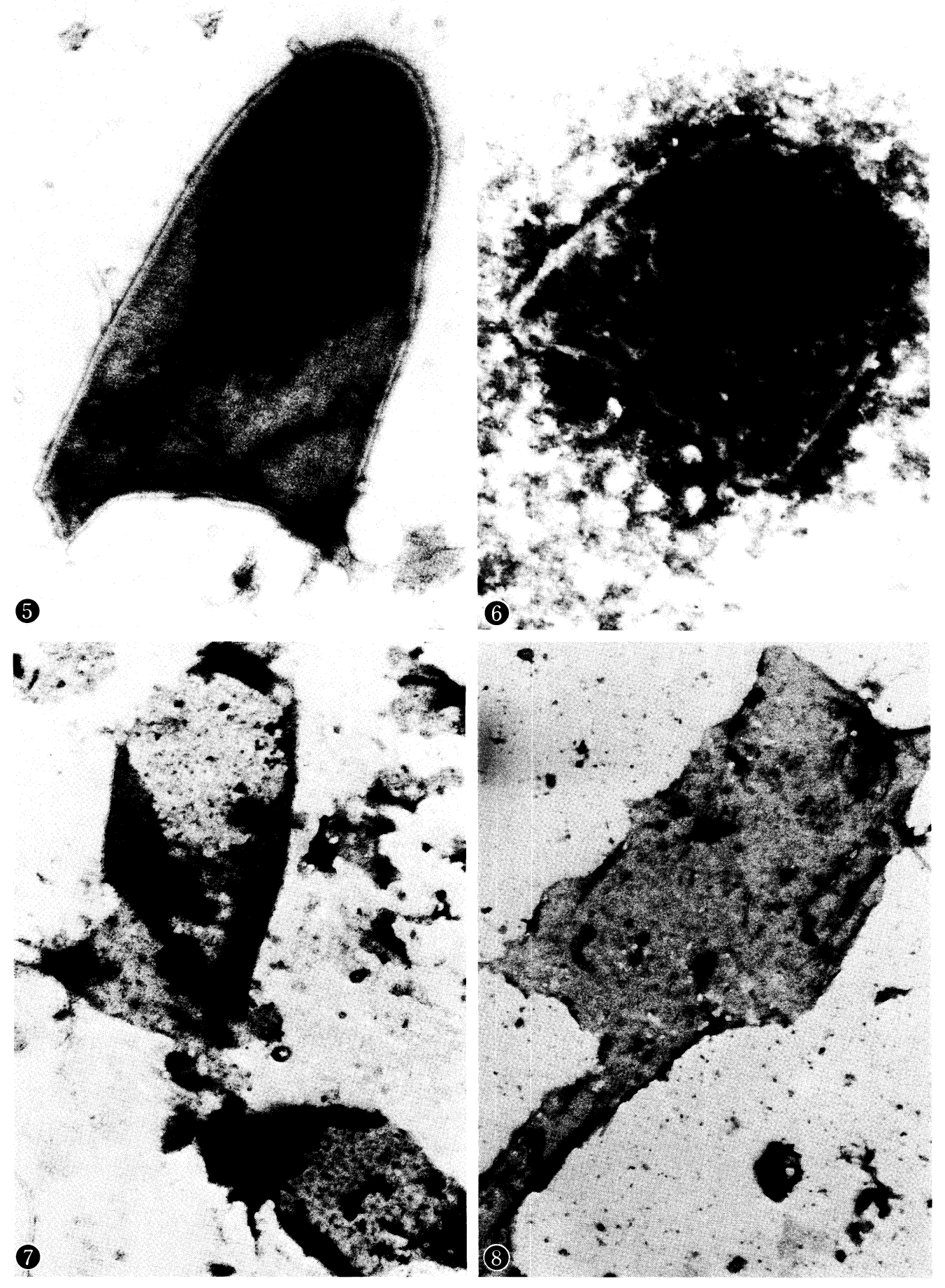

